\title{
Effect of a Natural Inulin-Containing Product, "Kikuimo Extract" on Intestinal Microbes and Gene Expression in the Liver and Adipose Tissue of Menopausal Monkeys
}

\author{
Shigeo Nakayama1, Fusako Mitsunaga ${ }^{2,3,4}$, Akira Maeda5 ${ }^{5}$, Shin Nakamura ${ }^{2,3,4^{*}}$ \\ ${ }^{1}$ Nihontounyoushoken Co. Ltd., lida, Japan \\ ${ }^{2}$ Primate Research Institute, Kyoto University, Inuyama, Japan \\ ${ }^{3} \mathrm{NPO}$ Primate Agora, Inuyama, Japan \\ ${ }^{4}$ Intelligence and Technology Lab Inc., Kaizu, Japan \\ ${ }^{5}$ Oasis Co. Ltd., Takarazuka, Japan \\ Email: "snakamura@primate-agora.jp
}

Received 1 March 2016; accepted 22 July 2016; published 25 July 2016

Copyright (C) 2016 by authors and Scientific Research Publishing Inc.

This work is licensed under the Creative Commons Attribution International License (CC BY).

http://creativecommons.org/licenses/by/4.0/

(c) (i) Open Access

\section{Abstract}

Inulin is a soluble and indigestible fiber derived from natural plants such as Jerusalem artichoke (Helianthus tuberosus), "Kikuimo". In the current study, a nutrigenomics approach was utilized to evaluate the in vivo function of "Kikuimo Extract" (KE) in ovariectomized cynomolgus macaque, a post-menopausal non-human primate model. KE was administered orally before feeding, for 3 months for the following examinations: 1) the effect of KE on intestinal microbes was examined by quantitative analyses of the intestinal bacteria using real-time PCR with DNA extracted from monkey feces; 2) the effect of KE on gene expression was investigated by real-time RT-PCR using RNA extracted from both the liver and adipose tissue of the monkeys. KE administration modulated menopause-mediated altered microbes to increase Lactobacilli, Veillonella, and Bacteroides in all monkeys. KE administration regulated the altered expression of functional genes, $S C A P, L D L R$, and $L X R A$ (lipid metabolism); GLUT-4 (glucose transport); CYP1A1 and CYP1A2 (drug metabolism); and $C Y P-17-2$ and $C Y P-19-2$ (E2 synthesis) in the menopausal monkeys. In menopausal monkeys, KE showed potent prebiotic effect on beneficial microflora and regulating effect on altered expression of functional genes associated with metabolism and E2 production. Thus, KE appears to be a practical functional food that alleviates the altered conditions of intestinal microbes and gene expression in the liver and adipose tissue in a menopausal state.

${ }^{*}$ Corresponding author.

How to cite this paper: Nakayama, S., Mitsunaga, F., Maeda, A. and Nakamura, S. (2016) Effect of a Natural InulinContaining Product, "Kikuimo Extract" on Intestinal Microbes and Gene Expression in the Liver and Adipose Tissue of Menopausal Monkeys. Food and Nutrition Sciences, 7, 752-762. http://dx.doi.org/10.4236/fns.2016.79076 


\section{Keywords}

\section{Functional Food, Prebiotics, Bacterial DNA, Gene Expression}

\section{Introduction}

Inulin is a soluble and indigestible fiber derived from natural plants such as Jerusalem artichoke (Helianthus tuberosus), chicory (Cichorium intybus), or yacon (Smallanthus sonchifolius). It is a fructose polymer (fructan) linked by beta [1] [2] glycosidic bonds with a glucose residue at one end [1] [2]. It is not digested in the small intestine, because humans and animals lack the enzyme that can digest the beta [1] [2] glycosidic bond [3]; however, inulin is fermented by microflora, especially by beneficial bacteria such as Bifidobacterium and Lactobacillus in the colon [4]-[8]. Because of this nature, inulin has been highlighted as one of the prominent functional foods or prebiotics, which are "indigestible food that selectively stimulates the growth and/or activity of gastrointestinal bacteria beneficially affecting the host" [9].

Recent studies on intestinal microorganisms unveil the impact of microflora on the occurrence of aging/ menopause-associated dysfunctions including intestinal disorders such as constipation [10], bowel inflammation [11] [12], and colon cancer [13] [14]. By maintaining a normal biofilm and luminal flora, beneficial bacteria afford resistance against pathogenic bacteria that invade or cause carcinogenesis in host [15]-[18]. In addition to their effect on the condition and function of digestive organs, accumulated evidence indicates that intestinal microflora plays important roles in the absorption of minerals such as calcium [19] and in lipid metabolism [20]. Furthermore, the composition of gut microflora has been shown to influence the extent of caloric intake, which in excess results in obesity [21] [22]. Therefore, as a prebiotic, inulin is expected to improve health and quality of life, especially in postmenopausal women who are at a high risk of metabolic syndrome and related disorders. There is limited information on the effect of inulin and/or related compounds on intestinal microflora and transcriptional event in main tissues of postmenopausal women. To examine the effect of functional food on menopause-mediated altered state, studies with non-human primate models would be the best, because of their biomedical nature including menstruation and menopause, which resemble those in humans.

In the present study, the effects of a natural inulin-containing product, "Kikuimo Extract" (KE) were examined on the intestinal microflora in ovariectomized (OVX) cynomolgus macaques, a post-menopausal monkey model. KE-mediated changes in the expression of functional genes in the liver and adipose tissue were investigated as well. KE was found to have unique effects on intestinal microflora and the gene expression in the liver and adipose tissue, providing invaluable nutraceutical evidences for use of KE as a functional food.

\section{Materials and Methods}

\subsection{Menopausal Monkeys}

Four female cynomolgus macaques (Macaca fascicularis), aged 18 to 21 years (3.3 kg to $3.9 \mathrm{~kg}$ ), were used for this study. The monkeys were housed in individual cages in a room with natural ventilation and temperature of $26^{\circ} \mathrm{C} \pm 4^{\circ} \mathrm{C}$ and humidity of $75 \% \pm 25 \%$ at the Animal Facility of Simian Conservation Breeding \& Research Center (SICONBREC) Inc. (Rizal, Philippines). They were fed $50 \mathrm{~g}$ of standard monkey chow (SINILOANH FEED CORPORATION, Laguna, Philippines) twice a day. Water was available ad libitum. Clinical observation was performed daily throughout the study period. Body weight was measured monthly. Blood was also collected for hematology, monthly.

Eight months before the administration of KE, the monkeys were ovariectomized (OVX) to establish a menopausal state and were used as a post-menopausal model [23] [24]. Plasma estradiol (E2) level was monitored weekly by ELISA using a commercially available kit (Neogen, Lexington, KY, USA) according to the manufacturer's instructions. In all OVX monkeys, plasma E2 reached an undetectable level after 2 weeks of ovariectomy, indicating a menopausal state.

All the experimental procedures were approved by and performed in accordance with the Guidelines of the Primate Research Institute of Kyoto University for the Care and Use of Laboratory Primates, based on the “Guide for the Care and Use of Laboratory Animals” by the US National Research Council, 1996 [25] [26]. 


\subsection{Kikuimo Extract (KE) and Its Administration}

KE was prepared by suspending dried “Kikuimo” powder (Nihontounyoushoken, Iida, Nagano, Japan), in saline at a concentration of $1 \mathrm{~g} / \mathrm{mL}$, and contained more than $50 \%$ inulin. KE was administered orally by using a stomach catheter twice a day, at a dose corresponding to the intake of $2 \mathrm{~g}$ of inulin/day, before feeding, for 3 months.

\subsection{Analysis of the Intestinal Microbes by Real-Time PCR}

Stool samples were obtained at $0,0.5,1,2$, and 3 months of KE administration. Fresh stool samples were collected in the morning from the floor, after cleaning the cage room, mixed immediately for uniformity, and stored below $-40^{\circ} \mathrm{C}$ until analysis.

DNA was extracted from 200 to $300 \mathrm{mg}$ of frozen stool by using a QIAamp DNA Stool Mini Kit (Qiagen, Valencia, CA, USA) according to the manufacturer's instructions. The concentration and purity of the obtained DNA were determined by measuring the absorbance at 260 and $280 \mathrm{~nm}$.

Real-time PCR was performed to quantify DNA of 16S rRNA gene from 11 bacterial species/groups by utilizing an SYBR Green detection system with an ABI Prism 7700 Sequence Detection System (Applied Biosystems, Foster City, CA, USA) and specific primers for target bacteria. The sequences of their primers (F: forward $5^{\prime}$ to $3^{\prime}$, R: reverse $5^{\prime}$ to $3^{\prime}$ ) are available upon request. The abbreviations of the 11 target bacteria are as follows. Lactobacilli: Lacto, Bifidobacteria: Bif, Clostridium butyricum: Cbu, Faecalibacterium prausnitzii: Fpr, Enterococci: Efs, Bacteroides: Bac, Ruminococcus albus: Ral, Veillonella: Veillo, C. clostridiiforme: Ccl, C. perfringens: Cpe, and Desulfovibrio: Dsv. A universal primer (Uni) set was used to amplify conserved regions of the 16S rRNA gene of bacteria and was utilized as a reference value to express the relative quantity of target bacteria as described below. The PCR reaction was performed in a 10- $\mu \mathrm{L}$ (total volume) mixture containing 5 $\mu \mathrm{L}$ of $2 \times$ SYBR Premix Ex Taq (Takara Bio, Otsu, Japan), $0.2 \mu \mathrm{L}$ of 50× ROX Reference Dye (Takara Bio, Otsu, Japan), $0.1 \mu \mathrm{M}$ each primer, and $25 \mathrm{ng}$ of template DNA. The conditions for PCR were $95^{\circ} \mathrm{C}$ for $10 \mathrm{~s}$ and 35 cycles of $95^{\circ} \mathrm{C}$ for $5 \mathrm{~s}$ and $60^{\circ} \mathrm{C}$ for $30 \mathrm{~s}$. After each amplification, dissociation curve analysis was performed to confirm PCR specificity. DNA standards for calibration were prepared from serially diluted PCR products that were previously amplified from macaque stool DNA using the Uni primers. To express the quantity of target bacterial DNA in a stool sample, the quantity of interest was calculated by dividing the amount of target DNA by that obtained with Uni for normalization. Amplification and detection were performed in duplicate.

\subsection{RNA Preparation}

Biopsy tissue samples, liver and subcutaneous adipose, were obtained pre- and post-administration of KE, respectively. RNA was prepared as described previously [27]. Briefly, total RNA was extracted from the harvested tissue samples using Isogen (Nippon gene, Tokyo, Japan) and DNase-treated in the aqueous phase using the RNase-free DNase Set (Qiagen, Valencia, CA). The extracted RNA was further purified using an RNeasyMinElute Cleanup Kit (Qiagen), and the quantity and purity were evaluated photometrically at $260 \mathrm{~nm}, 280 \mathrm{~nm}$, and 320 nm using an Ultrospec 2000 (Pharmacia Biotech/GE Healthcare, Uppsala, Sweden).

\subsection{Quantitative Gene Expression Analysis by Real-Time Reverse Transcription (RT)-PCR}

RT reaction was performed to synthesize cDNA from the isolated total RNA by using PrimeScript Reverse Transcriptase (Takara Bio Inc., Otsu, Japan) with RNase Inhibitor (Takara Bio Inc.), dNTP Mixture (Takara Bio Inc.), and OligodT Primer (Takara Bio Inc.). The real-time PCR was performed by the ABI Prism 7700 Sequence Detector System (Applied Biosystems, Foster City, CA, USA) and/or the Mx3000P QPCR System (Agilent Technologies, Inc.) using a reaction mixture containing cDNA, SYBR Premix Ex Taq kit (Takara Bio Inc.) and specific primers for genes listed in Table 1 and Table 2. The sequences of primers (F: forward 5' to 3', $\mathrm{R}$ : reverse $5^{\prime}$ to $3^{\prime}$ ) are available upon request. In each run, a standard curve was generated by serially diluted GAPDH amplicon, as described previously [27], to calculate the cDNA copy number of genes. The quantity of mRNA of interest was expressed as its ratio against that of a suitable reference gene, low-density lipoprotein receptor-related protein 10 (LRP10) [28].

To analyze differentially expressed genes, the Fold Change (FC) of samples obtained post administration of KE versus those obtained pre-administration of KE was calculated. Genes with FC greater than 1.5 and -1.5 were extracted for $50 \%$ upregulation or downregulation induced by KE administration. 
Table 1. Changes of gene expression in liver by kikuimo extract analyzed by quantitative real time RT-PCR $(n=4)$.

\begin{tabular}{|c|c|c|c|c|}
\hline Functional category & Gene symbol & Gene name & $\begin{array}{r}\text { Mean } \mathrm{f} \\
(\mathrm{Pp}\end{array}$ & $\begin{array}{l}\text { d change } \\
\text { /Pre) }\end{array}$ \\
\hline \multirow{10}{*}{ Lipid metabolism } & SCARB1 & Scavenger receptor class B, member 1 & -1.3 & \\
\hline & $L D L R$ & Low density lipoprotein receptor & -1.1 & \\
\hline & $V L D L R$ & Very low density lipoprotein receptor & -1.1 & \\
\hline & SCAP & SREBF chaperone & -1.9 & Down \\
\hline & SREBF1 & $\begin{array}{l}\text { Sterol regulatory element binding } \\
\text { transcription factor } 1 \text { (SREBP-1c) }\end{array}$ & 1.6 & Up \\
\hline & SREBFF2 & Sterol regulatory element binding transcription factor 2 (SREBP-2) & -1.3 & \\
\hline & DHCR24 & 24-dehydrocholesterol reductase (Seladin-1) & 1.1 & \\
\hline & DHCR7 & 7-dehydrocholesterol reductase & 1.6 & Up \\
\hline & ABCA1 & ATP-binding cassette, sub-family A (ABC1), member 1 & 1.5 & Up \\
\hline & $P P A R G$ & Peroxisome proliferator-activated receptor gamma & 1.0 & \\
\hline \multirow{2}{*}{$\begin{array}{c}\text { Glucose } \\
\text { metabolism }\end{array}$} & $S L C 2 A 1$ & $\begin{array}{c}\text { Solute carrier family } 2 \\
\text { (facilitated glucose transporter), member } 1 \text { (GLUT1) }\end{array}$ & -1.3 & \\
\hline & $S L C 2 A 4$ & $\begin{array}{c}\text { Solute carrier family } 2 \\
\text { (facilitated glucose transporter), member } 4 \text { (GLUT4) }\end{array}$ & 2.6 & Up \\
\hline Oxidative stress & $C A T$ & Catalase & -1.3 & \\
\hline \multirow{3}{*}{ Immuno-response } & IL12 & Interleukin 12 & 2.2 & Up \\
\hline & IL18 & Interleukin 18 & -1.2 & \\
\hline & FOXP3 & Forkhead box P3 & -1.4 & \\
\hline \multirow{5}{*}{$\begin{array}{l}\text { Steroid hormone } \\
\text { synthesis/receptors }\end{array}$} & CYP17A1 & Cytochrome P450, family 17, subfamily A, polypeptide 1 (CYP17) & -1.4 & \\
\hline & STAR & Steroidogenic acute regulatory protein & -1.1 & \\
\hline & ESR1 & Estrogen receptor 1 Esr1(ER alpha) & -1.7 & Down \\
\hline & ESR2 & Estrogen receptor 2 (ER beta) & -1.2 & \\
\hline & $P G R$ & Progesterone receptor (PR) & -1.0 & \\
\hline \multirow{10}{*}{ CYPs } & CYP1A1 & Cytochrome P450, family 1, subfamily A, polypeptide 1 & -2.6 & Down \\
\hline & CYP1A2 & Cytochrome P450, family 1, subfamily A, polypeptide 2 & -1.9 & Down \\
\hline & CYP2A6 & Cytochrome P450, family 2, subfamily A, polypeptide 6 & -1.2 & \\
\hline & СYP2B6 & Cytochrome P450, family 2, subfamily B, polypeptide 6 & 1.2 & \\
\hline & CYP2C9 & Cytochrome P450, family 2, subfamily C, polypeptide 9 & -1.4 & \\
\hline & СYР2C19 & Cytochrome P450, family 2, subfamily C, polypeptide 19 & -1.2 & \\
\hline & CYP2D6 & Cytochrome P450, family 2, subfamily D, polypeptide 6 & 1.2 & \\
\hline & CYP2E1 & Cytochrome P450, family 2, subfamily E, polypeptide 1 & -1.5 & Down \\
\hline & СYР3А4 & Cytochrome P450, family 3, subfamily A, polypeptide 4 & 1.3 & \\
\hline & CYP3A5 & Cytochrome P450, family 3, subfamily A, polypeptide 5 & 2.1 & Up \\
\hline
\end{tabular}


Table 2. Changes of gene expression in adipose tissue by kikuimo extrct analyzed by quantitative real time RT-PCR $(n=4)$.

\begin{tabular}{|c|c|c|c|c|}
\hline Functional category & Gene symbol & Gene name & $\begin{array}{l}\text { Mean } \mathrm{f} \\
\quad(\mathrm{Ppc}\end{array}$ & $\begin{array}{l}\text { change } \\
\text { Pre) }\end{array}$ \\
\hline \multirow{11}{*}{ Lipid metabolism } & $L E P$ & Leptin & 1.2 & \\
\hline & $A D I P O Q$ & Adiponectin, C1Q and collagen domain containing & 1.1 & \\
\hline & LDLR & Low density lipoprotein receptor & -2.0 & Down \\
\hline & NR1H & Nuclear receptor subfamily 1, group H, member 3 (LXR-a) & 2.0 & Up \\
\hline & SREBF1 & Sterol regulatory element binding transcription factor 1 (SREBP-1c) & 1.1 & \\
\hline & SREBF2 & Sterol regulatory element binding transcription factor 2 (SREBP-2) & 1.0 & \\
\hline & HMGCR & 3-hydroxy-3-methylglutaryl-CoA reductase (HMG-CoA reductase) & 1.0 & \\
\hline & DHCR24 & 24-dehydrocholesterol reductase (Seladin-1) & -1.0 & \\
\hline & $A B C A 1$ & ATP-binding cassette, sub-family A (ABC1), member 1 & 1.2 & \\
\hline & ABCA3 & ATP-binding cassette, sub-family A (ABC1), member 3 & 1.0 & \\
\hline & PPARG & Peroxisome proliferator-activated receptor gamma & 1.2 & \\
\hline \multirow{2}{*}{$\begin{array}{l}\text { Glucose } \\
\text { metabolism }\end{array}$} & $S L C 2 A 1$ & $\begin{array}{c}\text { Solute carrier family } 2 \\
\text { (facilitated glucose transporter), member } 1 \text { (GLUT1) }\end{array}$ & 1.3 & \\
\hline & $S L C 2 A 4$ & $\begin{array}{l}\text { Solute carrier family } 2 \\
\text { (facilitated glucose transporter), member } 4 \text { (GLUT4) }\end{array}$ & -1.1 & \\
\hline \multirow{5}{*}{$\begin{array}{l}\text { Steroid hormone } \\
\text { synthesis/receptors }\end{array}$} & CYP17A1 & Cytochrome P450, family 17, subfamily A, polypeptide 1 (CYP17) & -1.1 & \\
\hline & CYP19A1 & Cytochrome P450, family 19, subfamily A, polypeptide 1 (CYP19) & 2.2 & Up \\
\hline & STAR & Steroidogenic acute regulatory protein & 1.2 & \\
\hline & ESR 1 & Estrogen receptor 1 (ER alpha) & 1.0 & \\
\hline & ESR2 & Estrogen receptor 2 (ER beta) & 1.3 & \\
\hline
\end{tabular}

\section{Results}

\subsection{General Health Condition during KE Administration}

No monkey showed any digestive disorders such as appetite decrease and/or diarrhea during the administration period. There was no drastic change in the body weight of any animals. Main hematologic markers, peripheral blood leukocytes (pre-administration: $7.5 \times 10^{3} \pm 1.2 \times 10^{3} / \mu \mathrm{L}$; 3-month administration: $7.0 \times 10^{3} \pm 1.2 \times$ $10^{3} / \mu \mathrm{L}$ ), lymphocytes (pre-administration: $4.7 \times 10^{3} \pm 1.2 \times 10^{3} / \mu \mathrm{L}$; 3-month administration: $3.6 \times 10^{3} \pm 1.8 \times$ $10^{3} / \mu \mathrm{L}$ ), granulocytes (pre-administration: $2.7 \times 10^{3} \pm 2.3 \times 10^{3} / \mu \mathrm{L}$; 3-month administration: $3.3 \times 10^{3} \pm 2.0 \times$ $10^{3} / \mu \mathrm{L}$ ), erythrocytes (pre-administration: $7.0 \times 10^{6} \pm 0.4 \times 10^{6} / \mu \mathrm{L}$; 3-month administration: $6.5 \times 10^{6} \pm 0.4 \times$ $10^{6} / \mu \mathrm{L}$ ), platelets (pre-administration: $2.7 \times 10^{5} \pm 1.0 \times 10^{5} / \mu \mathrm{L}$; 3-month administration: $3.3 \times 10^{5} \pm 3.6 \times$ $10 \% / \mu \mathrm{L}$ ), hematocrit (pre-administration: $37.8 \% \pm 1.7 \%$; 3-month administration: $35.4 \pm 2.6 \%$ ), and hemoglobin content (pre-administration: $11.5 \pm 0.6 \mathrm{~g} / \mathrm{dL}$; 3-month administration: $10.6 \pm 0.9 \mathrm{~g} / \mathrm{dL}$ ), were within the normal range [29] during the study period in the four monkeys used.

\subsection{Effect of KE on Intestinal Microflora}

Figure 1 shows the level of intestinal microflora, expressed as the relative quantity of bacterial DNA in fecal samples during 3 months of KE administration in OVX post-menopausal monkeys. Two lactic bacteria, Lact and Efs, and Bac, increased more than 10-fold after 1 month of KE administration. The level of another lactic bacteria, Bif, and Veillo was within 10-fold of the pre-administration value at 3 months. A harmful bacterium, Cpe, decreased during 3 months of KE administration. No significant change was observed in the relative quantities of other bacteria, Fpr, Cbu, Ral, Ccl, and Dsv, when their post-administration values were compared with those obtained pre-KE administration (data not shown). 


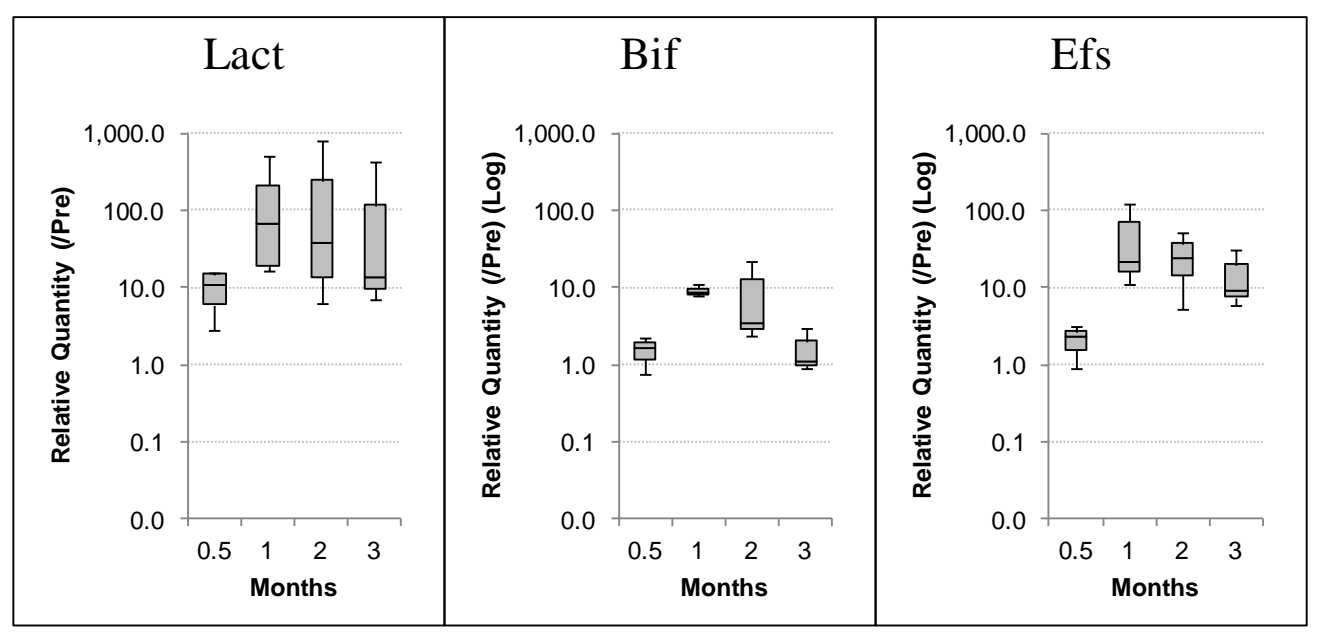

(a)

(b)

(c)

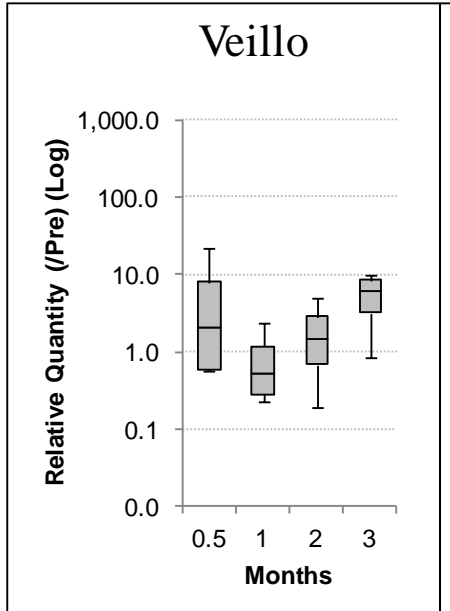

(d)

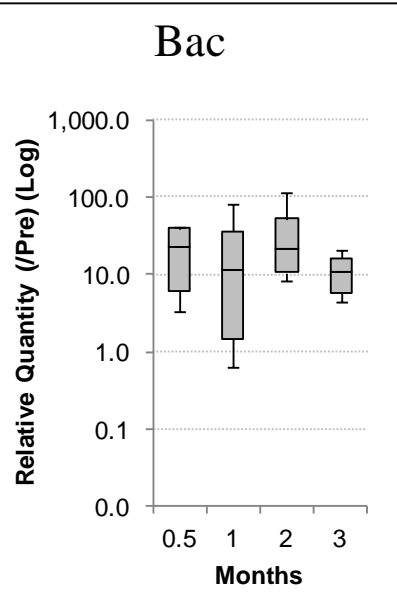

(e)

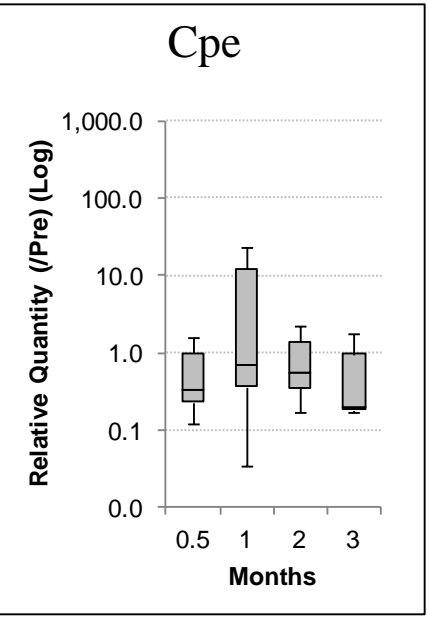

(f)

Figure 1. Changes in the amount of intestinal bacteria during 3 months Kikuimo Extract (KE) administration. The rectangles of the box plots span the first quartile to the third quartile and the segments inside the rectangles indicate the median. The whiskers above and below the rectangles indicate the minimum and maximum value $(n=4)$.

Figure 1 also illustrates a time course of the changing pattern for 6 bacterial groups, Lacto, Bif, Efs, Veillo, Bac and Cpe. Interestingly, the 6 bacteria showed a time dependent change in their increase or decrease at 2 weeks to 1 month after KE administration, and then at 3 months, they returned to their pre-administration levels or showed a rebound tendency.

\subsection{Effect of KE on Gene Expression in the Liver and Adipose Tissue}

Table 1 shows changes in gene expression in the liver after 3 months of KE administration in OVX postmenopausal monkeys. Among the lipid metabolism genes, the expression of SREBF1, DHCR7, and ABCA1 was upregulated while that of SCAP was downregulated. The expression of SLAC2A4/GLUT4, participating in glucose metabolism, was upregulated. The immune response-associated gene, $I L 12$, was also upregulated. Steroid hormone-related genes, ESR1/ER alpha, were downregulated. Among cytochrome P450 gene family, the expression of CYP1A1, CYP1A2, and CYP2E1 was downregulated but CYP3A5 was upregulated.

Table 2 shows changes in gene expression in adipose tissue, which appeared to be different from those observed in the liver. Among the lipid metabolism genes, the expression of $L D L R$ was downregulated but $N R 1 H 3 / L X R-a$ was upregulated. It is noteworthy that the expression of CYP19A1, which participates in the synthesis of steroid hormone, including estrogen, was upregulated. 


\section{Discussion}

Detailed information regarding intestinal bacteria profile in a postmenopausal state is limited, although intestinal microbes were thought to be associated with postmenopausal dysfunctions, constipation [10], bowel inflammation [11] [12], and other related disorders. Inulin is a well-known prebiotic and affects beneficial bacteria, Bif and Lacto [4]-[8]. This is the reason why people have concerns regarding functional foods containing inulin and its derivatives, which not only produce beneficial gastrointestinal microbes, but also improve the health of the host. "Kikuimo" is the Japanese name of J. artichoke, and KE is a natural inulin-containing functional food prepared from J. artichoke. In the present study, changes in 11 intestinal microflora, Lacto, Bif, Cbu, Fpr, Efs, Bac, Ral, Veillo, Ccl, Cpe, and Dsv were examined before and during the 3-month administration of KE by using a post-menopausal monkey model. The changes in the intestinal microflora would be expected to influence the metabolic system of the host. Therefore, we also investigated the effect of KE administration on the expression of genes associated with following functions; lipid and glucose metabolism, immunoresponse, steroid hormone and receptor synthesis, and hypoxia, and genes belonging to cytochrome P450 family in both the liver and adipose tissue of menopausal monkeys.

The increase in Lacto population was observed in all monkeys, at the end of 3 months. The quantity of Lacto relative to the whole detectable fecal bacteria increased rapidly, with a peak within first month and then declined gradually in the next 2 months, but was still approximately 10-fold greater than the value observed before KE administration. On the contrary, the increase in Bif was lower, and this organism seemed to be less able to utilize inulin than Lacto. In previous human studies, Bif population was reported to increase markedly in response to inulin administration, whereas Lacto did not [4] [30]. In the current study, the KE administration and observation periods were both 3 months, which was longer than that employed in previous human studies (less than 1 month); therefore, the decline in Bif could be observed after their peak (Figure 1(b)), which would have been unrecognized in a shorter observation period. Efs, another group of lactic acid bacteria, showed significant increase in all of the monkeys. As Efs has been known to use glucose for production of lactic acid [31], it could utilize glucose at the end of the fructose chain of inulin. The Veillo population also increased after KE administration, which has not been reported thus far. The characteristics of Veillo in human intestinal microflora have not been elucidated despite its prevalence in the intestine [32] [33]. There is a report on Veillo infection in the sinuses, lungs, or central nervous system and it is regarded as a pathogen [34]. On the other hand, Veillo is known to utilize lactic acid for volatile fatty acid production and has an inhibitory effect on pathogenic bacteria such as Salmonella typhimurium or Escherichia coli 0157 in vitro [35]. Thus, Veillo multiplies by utilizing the lactic acid produced by Lact, and may be beneficial for the host by inhibiting the growth of pathogenic enterobacteria. Bac was reported to increase in quantity gradually during the 3 months of KE administration in the monkeys. Bac is a predominant bacteria in the human intestine and is reported to metabolize oligofructose, although they prefer glucose [36] [37]. It is likely that this major bacterial group could compete with Bif or Lacto, or they might profit from the glucose at the end of the inulin chains. No changes were observed in Cpe level at 3 months of KE administration, because Cpe can ferment glucose more efficiently than Efs in vivo [38] and is also acid-resistant [39]. The population ratio of CPe decreased, suggesting that KE administration declined the relative number of Cpe among intestinal microflora.

KE administration modulated the altered expression of functional genes in the liver and adipose tissue of menopausal monkeys (Table 1 and Table 2). Among the lipid metabolizing genes in the liver, KE administration up regulated the expression of both, SREBF1/SREBP-1C and DHCR7, but down regulated SCAP. SREBF1/ SREBP-1C and DHCR7 are the limiting factors for the synthesis of fatty acid, triglyceride, and cholesterol, respectively [40] [41]. SCAP was associated with both fatty acid/triglyceride and cholesterol syntheses in the liver, because liver-specific Scap-knockout mice exhibited a significant decrease in hepatic fatty acid, triglyceride, and cholesterol [40] [42]. These suggest that the KE-mediated down regulation of SCAP results in the decrease of hepatic fatty acid/triglyceride and cholesterol. KE administration also upregulated the expression of hepatic $A B C A 1$, which played a role in cholesterol efflux to HDL apoproteins, apoA-1 and apoE, and regulated the pathogenesis of atherosclerosis and/or Alzheimer's disease [43]. The upregulated expression of $A B C A 1$ was modulated by $N R 1 H 3 / L X R-a$ [43]. Interestingly, KE upregulated the expression of $N R 1 H 3 / L X R-a$ in adipose tissue (Table 2). $N R 1 H 3 / L X R-a$ is the member of the nuclear receptor superfamily that is activated by oxysterols. In response to ligand binding, $N R 1 H 3 / L X R-a$ controls the expression of genes involved in the catabolism, transport, and uptake of cholesterol and its metabolites [44]. NR1H3/LXR- $a$ was also suggested to have an ameliorative 
effect on atherosclerosis in suppressed state of LDLR [45]. This suggests that KE can alleviate lipid metabolism by modulating the altered expression of key lipid metabolism genes in menopausal state. Furthermore, KE administration upregulated the expression of SLC2A4/GLUT4 in the liver. SLC2A4/GLUT4 was reported to ameliorate glycometabolism and insulin resistance in diabetic mice [46]. The KE-induced upregulation of the expression of SLC2A4/GLUT4 appears to have beneficial effect in regulating glucose metabolism and improving insulin resistance in menopausal state.

Among the immunoresponse genes, hepatic IL12 was upregulated by KE, indicating activation of NK and NKT cells, which results in the induction of IFN- $\gamma$ production [47] KE administration modulated the expression of genes related to the synthesis of steroidal hormone and receptors anddownregulatedESR1in the liver and upregulated CYP19A1 in adipose tissue. CYP19A1 is known as aromatase and involved in estrogen production; the KE-mediated upregulation of CYP19A1 appears to complement a decline in female hormone during menopause [48] [49]. In the liver, downregulation or upregulation of CYPS family genes was observed in KE-administered menopausal monkeys (Table 1). CYPs are involved in the metabolism of drugs, chemicals, and endogenous substrates. Hepatic CYPs are also involved in the pathogenesis of several liver diseases through CYPmediated activation of drugs to toxic metabolites [50]. Downregulation of CYP1A1, CYP1A2, and CYP2E1 would protect the liver against diseases by modulating CYP-mediated production of toxic metabolites. The effect of KE on the altered expression of functional genes in the liver and adipose tissue could be mediated through Short-Chain Fatty Acids (SCFAs) produced by beneficial intestinal bacteria [51], although the mechanism of SCFA-regulated gene expression has not been completely understood.

\section{Conclusion}

In conclusion, KE has potent prebiotic effect in modulating the number of beneficial bacteria, Lacto, Efs, Bif, and Veillo, following its long-term administration to menopausal monkeys, suggesting that inulin-containing foods ameliorate altered intestinal microbes in a menopausal state. KE also ameliorated the altered expression of genes involved in lipid and glucose metabolism; immunoresponse; estrogen synthesis; and metabolism of drugs, chemicals, and endogenous substrates, indicating its alleviating effect on menopause-mediated dysfunctions via modulation of gene expression in the liver and/or adipose tissue.

\section{Conflict of Interests}

The authors declare that they have no competing interests.

\section{References}

[1] Calub, T.M., Waterhouse, A.L. and French, A.D. (1990) Conformational Analysis of Inulobiose by Molecular Mechanics. Carbohydrate Research, 207, 221-235. http://dx.doi.org/10.1016/0008-6215(90)84050-5

[2] Liu, J., Waterhouse, A.L. and Chatterton, N.J. (1993) Proton and Carbon NMR Chemical-Shift Assignments for [BetaD-Fru f-(2-->1)]3-(2<==>1)-Alpha-D-Glc p (Nystose) and [Beta-D-Fru f-(2-->1)] 4-(2<==>1)-Alpha-D-Glc p (1,1,1Kestopentaose) from Two-Dimensional NMR Spectral Measurements. Carbohydrate Research, 245, 11-19. http://dx.doi.org/10.1016/0008-6215(93)80056-K

[3] Roberfroid, M.B. (2005) Introducing Inulin-Type Fructans. The British Journal of Nutrition, 93, S13-S25. http://dx.doi.org/10.1079/bjn20041350

[4] Kleessen, B., Svkura, B., Zunft, H.-J. and Blaut, M. (1997) Effects of Inulin and Lactose on Fecal Microflora, Microbial Activity, and Bowel Habit in Elderly Constipated Persons. The American Journal of Clinical Nutrition, 65, 13971402.

[5] Niness, K.R. (1999) Inulin and Oligofructose: What Are They? The Journal of Nutrition, 129, 1402S-1406S.

[6] Kleessen, B., Hartmann, L. and Blaut, M. (2001) Oligofructose and Long-Chain Inulin: Influence on the Intestinal Microbial Ecology of Rats Associated with a Human Faecal Flora. The British Journal of Nutrition, 86, 291-300. http://dx.doi.org/10.1079/BJN2001403

[7] Langlands, S.J., Hopkins, M.J., Coleman, N. and Cummings, J.H. (2004) Prebiotic Carbohydrates Modify the Mucosa Associated Microflora of the Human Large Bowel. Gut, 53, 1610-1616. http://dx.doi.org/10.1136/gut.2003.037580

[8] Lesniewska, V., Rowland, I., Cani, P.D., Neyrinck, A.M., Delzenne, N.M. and Naughton, P.J. (2006) Effect on Components of the Intestinal Microflora and Plasma Neuropeptide Levels of Feeding Lactobacillus delbrueckii, Bifidobacterium lactis, and Inulin to Adult and Ederly Rats. Applied and Environmental Microbiology, 72, 6533-6538. 
http://dx.doi.org/10.1128/AEM.00915-06

[9] Gibson, G.R. and Roberfroid, M.B. (1995) Dietary Modulation of the Human Colonic Microbiota: Introducing the Concept of Prebiotics. The Journal of Nutrition, 125, 1401-1412.

[10] Zutshi, M., Hull, T.L., Bast, J. and Hammel, J. (2007) Female Bowel Function: The Real Story. Diseases of the Colon and Rectum, 50, 351-358. http://dx.doi.org/10.1007/s10350-006-0758-0

[11] Matsumoto, S., Watanabe, N., Imaoka, A. and Okabe, Y. (2001) Preventive Effects of Bifidobacterium- and Lactobacillus-Fermented Milk on the Development of Inflammatory Bowel Disease in Senescence-Accelerated Mouse P1/Yit Strain Mice. Digestion, 64, 92-99. http://dx.doi.org/10.1159/000048846

[12] Lu, L. and Walker, W.A. (2001) Pathologic and Physiologic Interactions of Bacteria with the Gastrointestinal Epithelium. The American Journal of Nutrition, 73, 1124S-1130S.

[13] deMoreno de LeBlanc, A., Matar, C. and Perdigón, G. (2007) The Application of Probiotics in Cancer. The British Journal of Nutrition, 98, S105-S110. http://dx.doi.org/10.1017/s0007114507839602

[14] Biarc, J., Nguyen, I.S., Pini, A., Gossé, F., Richert, S., Thiersé, D., Van Dorsselaer, A., Leize-Wagner, E., Raul, F., Klein, J.P. and Schöller-Guinard, M. (2004) Carcinogenic Properties of Proteins with Pro-Inflammatory Activity from Streptococcus infantarius (Formerly S. bovis). Carcinogenesis, 25, 1477-1484. http://dx.doi.org/10.1093/carcin/bgh091

[15] Kleessen, B., Hartmann, L. and Blaut, M. (2003) Fructans in the Diet Cause Alterations of Intestinal Mucosal Architecture, Released Mucins and Mucosa-Associated Bifidobacteria in Gnotobiotic Rats. The British Journal of Nutrition, 89, 597-606. http://dx.doi.org/10.1079/BJN2002827

[16] Geboes, K.P., De Hertogh, G., De Preter, V., Luypaerts, A., Bammens, B., Evenepoel, P., Ghoos, Y., Geboes, K., Rutgeerts, P. and Verbeke, K. (2006) The Influence of Inulin on the Absorption of Nitrogen and the Production of Metabolites of Protein Fermentation in the Colon. The British Journal of Nutrition, 96, 1078-1086. http://dx.doi.org/10.1017/BJN20061936

[17] Sauer, J., Richter, K.K. and Pool-Zobel, B.L. (2007) Products Formed during Fermentation of the Prebiotic Inulin with Human Intestinal Flora Enhance Expression of Biotransformation Genes in Human Primary Colon Cells. The British Journal of Nutrition, 97, 928-937. http://dx.doi.org/10.1017/S0007114507666422

[18] Geier, M.S., Butler, R.N. and Howarth, G.S. (2006) Probiotics, Prebiotics and Synbiotics: A Role in Chemoprevention for Colorectal Cancer? Cancer Biology \& Therapy, 5, 1265-1269. http://dx.doi.org/10.4161/cbt.5.10.3296

[19] Scholz-Ahrens, K.E., Schaafsma, G., van den Heuvel, E.G. and Schrezenmeir, J. (2001) Effects of Prebiotics on Mineral Metabolism. The American Journal of Clinical Nutrition, 73, 459S-464S.

[20] Beylot, M. (2005) Effects of Inulin-Type Fructans on Lipid Metabolism in Man and in Animal Models. The British Journal of Nutrition, 93, S163-S168. http://dx.doi.org/10.1079/bjn20041339

[21] Turnbaugh, P.J., Ley, R.E., Mahowald, M.A., Magrini, V., Mardis, E.R. and Gordon, J.I. (2006) An Obesity-Associated Gut Microbiome with Increased Capacity for Energy Harvest. Nature, 444, 1027-1031. http://dx.doi.org/10.1038/nature05414

[22] Ley, R.E., Turnbaugh, P.J., Klein, S. and Gordon, J.I. (2006) Microbial Ecology: Human Gut Microbes Associated with Obesity. Nature, 444, 1022-1023. http://dx.doi.org/10.1038/4441022a

[23] Bellino, F.L. and Wise, P.M. (2003) Nonhuman Primate Models of Menopause Workshop. Biology of Reproduction, 68, 10-18. http://dx.doi.org/10.1095/biolreprod.102.005215

[24] Wood, C.E., Register, T.C., Franke, A.A., Anthony, M.S. and Cline, J.M. (2006) Dietary Soy Isoflavones Inhibit Estrogen Effects in the Postmenopausal Breast. Cancer Research, 66, 1241-1249. http://dx.doi.org/10.1158/0008-5472.CAN-05-2067

[25] National Research Council (1996) Guide for the Care and Use of Laboratory Animals. National Academy Press. Washington DC.

[26] Bayne, K. (1998) Developing Guidelines on the Care and Use of Animals. Annals of the New York Academy of Sciences, 862, 105-110. http://dx.doi.org/10.1111/j.1749-6632.1998.tb09122.x

[27] Jeong, A.R., Nakamura, S. and Mitsunaga, F. (2008) Gene Expression Profile of Th1 and Th2 Cytokines and Their Receptors in Human and Nonhuman Primates. Journal of Medical Primatology, 37, 290-296. http://dx.doi.org/10.1111/j.1600-0684.2008.00289.x

[28] Gabrielsson, B.G., Olofsson, L.E., Sjögren, A., Jernas, M., Elander, A., Lönn, M., et al. (2005) Evaluation of Reference Genes for Studies of Gene Expression in Human Adipose Tissue. Obesity Research, 13, 649-652. http://dx.doi.org/10.1038/oby.2005.72

[29] Matsuzawa, T., Nomura, M. and Takashi, U. (1993) Clinical Pathology Reference Ranges of Laboratory Animals. The Journal of Veterinary Medical Science, 55, 351-362. http://dx.doi.org/10.1292/jvms.55.351

[30] Bouhnik, Y., Raskine, L., Champion, K., Andrieux, C., Penven, S., Jacobs, H. and Simoneau, G. (2007) Prolonged 
Administration of Low-Dose Inulin Stimulates the Growth of Bifidobacteria in Humans. Nutrition Research, 27, 187193. http://dx.doi.org/10.1016/j.nutres.2007.01.013

[31] Harold, F.M. and Levin, E. (1974) Lactic Acid Translocation: Terminal Step in Glycolysis by Streptococcus faecalis. Journal of Bacteriology, 117, 1141-1148.

[32] Quintanilha, A.G., Zilberstein, B., Santos, M.A., Pajecki, D., Moura, E.G., Alves, P.R., Maluf-Filho, F. and Cecconello, I. (2007) A Novel Sampling Method for the Investigation of Gut Microbiota. World Journal of Gastroenterology, 13, 3990-3995. http://dx.doi.org/10.3748/wjg.v13.i29.3990

[33] Zilberstein, B., Quintanilha, A.G., Santos, M.A., Pajecki, D., Moura, E.G., Alves, P.R., MalufFilho, F., de Souza, J.A. and Gama-Rodrigues, J. (2007) Digestive Tract Microbiota in Healthy Volunteers. Clinics, 62, 47-54. http://dx.doi.org/10.1590/S1807-59322007000100008

[34] Bhatti, M.A. and Frank, M.O. (2000) Veillonella parvula Meningitis: Case Report and Review of Veillonella Infections. Clinical Infectious Diseases, 31, 839-840. http://dx.doi.org/10.1086/314046

[35] Hinton Jr., A. and Hume, M.E. (1995) Antibacterial Activity of the Metabolic By-Products of a Veillonella Species and Bacteroides fragilis. Anaerobe, 1, 121-127. http://dx.doi.org/10.1006/anae.1995.1007

[36] Gibson, G.R. and Wang, X. (1994) Bifidogenic Properties of Different Types of Fructo-Oligosaccharides. Food Microbiology, 11, 491-498. http://dx.doi.org/10.1006/fmic.1994.1055

[37] Van der Meulen, R., Makras, L., Verbrugghe, K., Adriany, T. and De Vuyst, L. (2006) In Vitro Kinetic Analysis of Oligofructose Consumption by Bacteroides and Bifidobacterium spp. Indicates Different Degradation Mechanisms. Applied and Environmental Microbiology, 72, 1006-1012. http://dx.doi.org/10.1128/AEM.72.2.1006-1012.2006

[38] Egert, M., de Graaf, A.A., Maathuis, A., de Waard, P., Plugge, C.M., Smidt, H., Deutz, N.E.P., Dijkema, C., de Vos, W.M. and Venema, K. (2007) Identification of Glucose-fermenting Bacteria Present in an in vitro Model of the Human Intestine by RNA-stable Isotope Probing. FEMS Microbiology Ecology, 60, 126-135. http://dx.doi.org/10.1111/j.1574-6941.2007.00281.x

[39] Cotter, P.D. and Hill, C. (2003) Surviving the Acid Test: Responses of Gram-positive Bacteria to Low pH. Microbiology and Molecular Biology Reviews, 67, 429-453. http://dx.doi.org/10.1128/MMBR.67.3.429-453.2003

[40] Horton, J.D., Goldstein, J.L. and Brown, M.S. (2002) SREBPs: Activators of the Complete Program of Cholesterol and Fatty Acid Synthesis in the Liver. The Journal of Clinical Investigation, 109, 1125-1131. http://dx.doi.org/10.1172/JCI0215593

[41] Korade, Z., Kenworthy, A.K. and Mirnics, K. (2009) Molecular Consequences of Altered Neuronal Cholesterol Biosynthesis. The Journal of Neuroscience Research, 87, 866-875. http://dx.doi.org/10.1002/jnr.21917

[42] Liang, G., Yang, J., Horton, J.D., Hammer, R.E., Goldstein, J.L. and Brown, M.S. (2002) Diminished Hepatic Response to Fasting/Refeeding and Liver X Receptor Agonists in Mice with Selective Deficiency of Sterol Regulatory element-Binding Protein-1c.The Journal of Biological Chemistry, 277, 9520-9528. http://dx.doi.org/10.1074/jbc.M111421200

[43] Koldamova, R., Fitz, N.F. and Lefterov, I. (2014) ATP-Binding Cassette Transporter A1: From Metabolism to Neurodegeneration. Neurobiology of Disease, 72, 13-21. http://dx.doi.org/10.1016/j.nbd.2014.05.007

[44] Laffitte, B.A., Joseph, S.B., Chen, M., Castrillo, A., Repa, J., Wilpitz, D., Mangelsdorf, D. and Tontonoz, P. (2003) The Phospholipid Transfer Protein Gene Is a Liver X Receptor Target Expressed by Macrophages in Atherosclerotic Lesions. Molecular and Cellular Biology, 23, 2182-2191. http://dx.doi.org/10.1128/MCB.23.6.2182-2191.2003

[45] Tangirala, R.K., Bischoff, E.D., Joseph, S.B., Wagner, B.L., Walczak, R., Laffitte, B.A., Daige, C.L., Thomas, D., Heyman, R.A., Mangelsdorf, D.J., Wang, X., Lusis, A.J., Tontonoz, P. and Schulman, I.G. (2002) Identification of Liver X Receptors as Macrophage Inhibitors of Atherosclerosis. Proceedings of the National Academy of Sciences of the United States of America, 99, 11896-11901. http://dx.doi.org/10.1073/pnas.182199799

[46] Chen, L.N., Lyu, J., Yang, X.F., Ji, W.J., Yuan, B.X., Chen, M.X., Ma, X. and Wang, B. (2013) Liraglutide Ameliorates Glycometabolism and Insulin Resistance through the Upregulation of GLUT4 in Diabetic KKAy Mice. International Journal of Molecular Medicine, 32, 892-900.

[47] Seki, S., Nakashima, H., Nakashima, M. and Kinoshita, M. (2011) Antitumor Immunity Produced by the Liver Kupffer Cells, NK Cells, NKT Cells, and $\mathrm{CD}^{+} \mathrm{CD}^{2} 2^{+} \mathrm{T}$ Cells. Clinical \& Developmental Immunology, 2011, Article ID: 868345. http://dx.doi.org/10.1155/2011/868345

[48] Simpson, E.R., Mahendroo, M.S., Means, G.D., Kilgore, M.W., Hinshelwood, M.M., Graham-Lorence, S., Amarneh, B., Ito, Y., Fisher, C.R., Michael, M.D., Mendelson, C.R. and Bulun, S.E. (1994) Aromatase Cytochrome P450, the Enzyme Responsible for Estrogen Biosynthesis. Endocrine Reviews, 15, 342-355.

[49] Flote, V.G., Furberg, A.S., McTiernan, A., Frydenberg, H., Ursin, G., Iversen, A., Lofteroed, T., Ellison, P.T., Wist, E.A., Egeland, T., Wilsgaard, T., Makar, K.W., Chang-Claude, J. and Thune, I. (2014) Gene Variations in OestrogenPathways, CYP19A1, Daily 17 $\beta$-Estradiol and Mammographic Density Phenotypes in Premenopausal Women. Breast 
Cancer Research, 16, 499. http://dx.doi.org/10.1186/s13058-014-0499-2

[50] Villeneuve, J.P. and Pichette, V. (2004) Cytochrome P450 and Liver Diseases. Current Drug Metabolism, 5, $273-282$. http://dx.doi.org/10.2174/1389200043335531

[51] Tan, J., McKenzie, C., Potamitis, M., Thorburn, A.N., Mackay, C.R. and Macia, L. (2014) The Role of Short-Chain Fatty Acids in Health and Disease. Advances in Immunology, 121, 91-119. http://dx.doi.org/10.1016/B978-0-12-800100-4.00003-9

\section{Submit or recommend next manuscript to SCIRP and we will provide best service for you:}

Accepting pre-submission inquiries through Email, Facebook, Linkedin, Twitter, etc A wide selection of journals (inclusive of 9 subjects, more than 200 journals)

Providing a 24-hour high-quality service

User-friendly online submission system

Fair and swift peer-review system

Efficient typesetting and proofreading procedure

Display of the result of downloads and visits, as well as the number of cited articles

Maximum dissemination of your research work

Submit your manuscript at: http://papersubmission.scirp.org/ 